\title{
Human Endothelial Cells in Culture*
}

\author{
Којі Үамамото \\ Department of Anatomy (Prof. Y. TAKeshige), Kurume University School of Medicine, \\ Kurume, Japan
}

Received May 11, 1978

Summary. Daily changes of cultured endothelial cells were observed by phase contrast microscopy, time-lapse microcinematography and electron microscopy.

By light microscopy, the cultured cells are polygonal in shape and form monolayered clusters. However, they become elongated like fibroblasts between 10 and 14 days. Proliferation of the cultured cells by mitotic division could not be recognized by cinematographic observation. On the contrary, many binucleate cells occurred in the periphery of the cluster throughout the proliferation period, suggesting that the cells proliferate here, at least predominantly, by amitotic division.

By electron microscopy, specific endothelial granules and two types of filaments (about $120 \AA$ and $65 \AA$ in diameter) were observed in the cultured endothelial cells. The combined cinematographic and electron microscopic observations suggested that the thinner filaments may be contractile elements involved in the movement of the cultured cells.

Extending from the work of Maruyama (1963), human endothelial cells, have been purely isolated and cultured (Lewis et al., 1973; JAFFE et al., 1973; GimBrone et al., 1974; Haudenschild et al., 1975, 1976). The identification of these cultured cells as endothelial cells has been established both morphologically and immunologically (JAFFE et al., 1973).

Isolated endothelial cells in cultured conditions rapidly increase in number, and autoradiographic studies of cultured cells with ${ }^{3} \mathrm{H}$-thymidine have shown an increase in DNA synthesis during the cell growth (Gimbrone et al., 1974; HAudenshild et al., 1976). However, morphological data have not confirmed yet that such a rapid cell growth of cultured human endothelial cells occurs by mitotic proliferation, although HAUDENSCHILD and co-workers (1975) suggest it. On the other hand, occurrence of binucleate cells was noted in the endothelium of normal human arteries (CотTON and WARTMAN, 1961) and in cultured endothelial cells (MARUYAMA, 1963).

The purpose of this study is to ascertain whether there is some relation between the proliferation of endothelial cells and the presence of binucleate cells in cultured conditions, and to examine the more detailed fine structures of cultured human endothelial cells through their life cycle.

* This work was supported by Research Grant 177025 from the Ministry of Education. 


\section{MATERIALS AND METHODS}

After isolation of human umbilical cords, the umbilical veins were rinsed with Hanks balanced salt solution in order to wash out clots of blood, infused with the same solution containing $1 \mathrm{mg} / \mathrm{ml}$ collagenase (Type I, Sigma) for $20-30 \mathrm{~min}$ at $37^{\circ} \mathrm{C}$, and gently flushed out with the solution. The effluent was collected in sterile conical centrifuge tubes and the endothelial cells were isolated by centrifugation at 1,000 rpm for $5 \mathrm{~min}$. The cells were cultured with Eagle's minimal essential media supplemented with $10 \%$ fetal calf serum and 1\% L-glutamine solution in plastic Petri dishes (Falcon). The cultured cells were incubated at $37^{\circ} \mathrm{C}$ under $5 \% \quad \mathrm{CO}_{2}$ air atmosphere. The media were replaced every 3 days with completely fresh ones.

All cultured cells were examined under the phase contrast microscope. The proliferation and other behavior of the cultured endothelial cells were analyzed by the use of the time-lapse microcinematoscope.

For transmission electron microscope (TEM) observation, the cultured cells were fixed in a Petri dish with $2.5 \%$ glutaraldehyde in $0.1 \mathrm{M}$ cacodylate buffer $(\mathrm{pH} 7.4)$ for $1 \mathrm{hr}$, post-fixed with $2 \% \mathrm{OsO}_{4}$ in the same buffer for $1 \mathrm{hr}$, dehydrated in ethanol, and embedded in epoxy resins. The embedded cultured cells were frozen by liquid nitrogen and separated from the Petri dish. The ultra-thin sections were made by a Porter-Blum ultramicrotome, stained with uranyl acetate and lead hydroxide, and observed with the Hitachi HU-12AS or the $\mathrm{H}-500$ type TEM.

For the scanning electron microscope (SEM) observation, the cultured cells were fixed and dehydrated in a Petri dish by the same methods as for TEM, critical point dried, coated with gold by evaporation, and observed with the Hitachi HFS-2 type field emission SEM.

\section{RESULTS}

Isolated endothelial cells from human umbilical veins show a rather round or oval shape at the beginning. Within $2-4 \mathrm{hrs}$, the cells become attached to the substratum and spread as a monolayer cell cluster on the dish.

Between 2 and 3 days after the culture, the endothelial cells were remarkably increased in number and formed several cell clusters (Fig. 1). Active movement of the cells could be seen at the periphery of each cluster. However, their mitotic division could not be observed either with the phase contrast microscope nor with the time-lapse microcinematoscope.

Abundant binucleate cultured cells appeared in the peripheral regions of each cluster (Fig. 2a, b). The two nuclei of such cells were almost equal in size and shape and were often located close to each other. Figure $2 \mathrm{~b}$ is a phase contrast micrograph which suggests that a binucleate cell is dividing into two daughter cells by amitotic division.

By TEM, such cultured cells are easily identified with endothelial cells by the presence of specific endothelial granules (Weibel-Palade granules), since these granules do not appear in cultured fibroblasts and smooth muscle cells (JAFFE et al., 1973; 


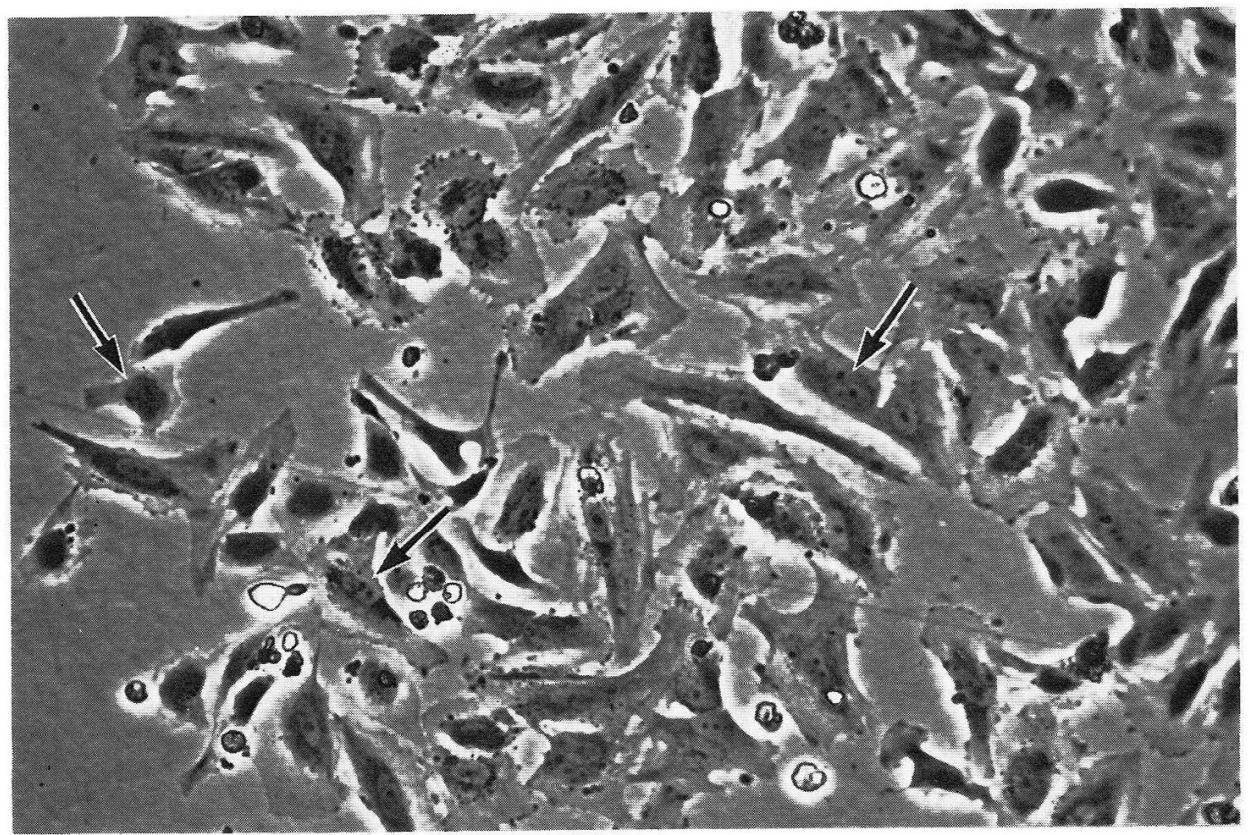

Fig. 1. Phase contrast micrograph of cultured endothelial cells at a peripheral region of cluster. Abundant binucleate cells have appeared (arrows). 3 day culture. $\times 250$

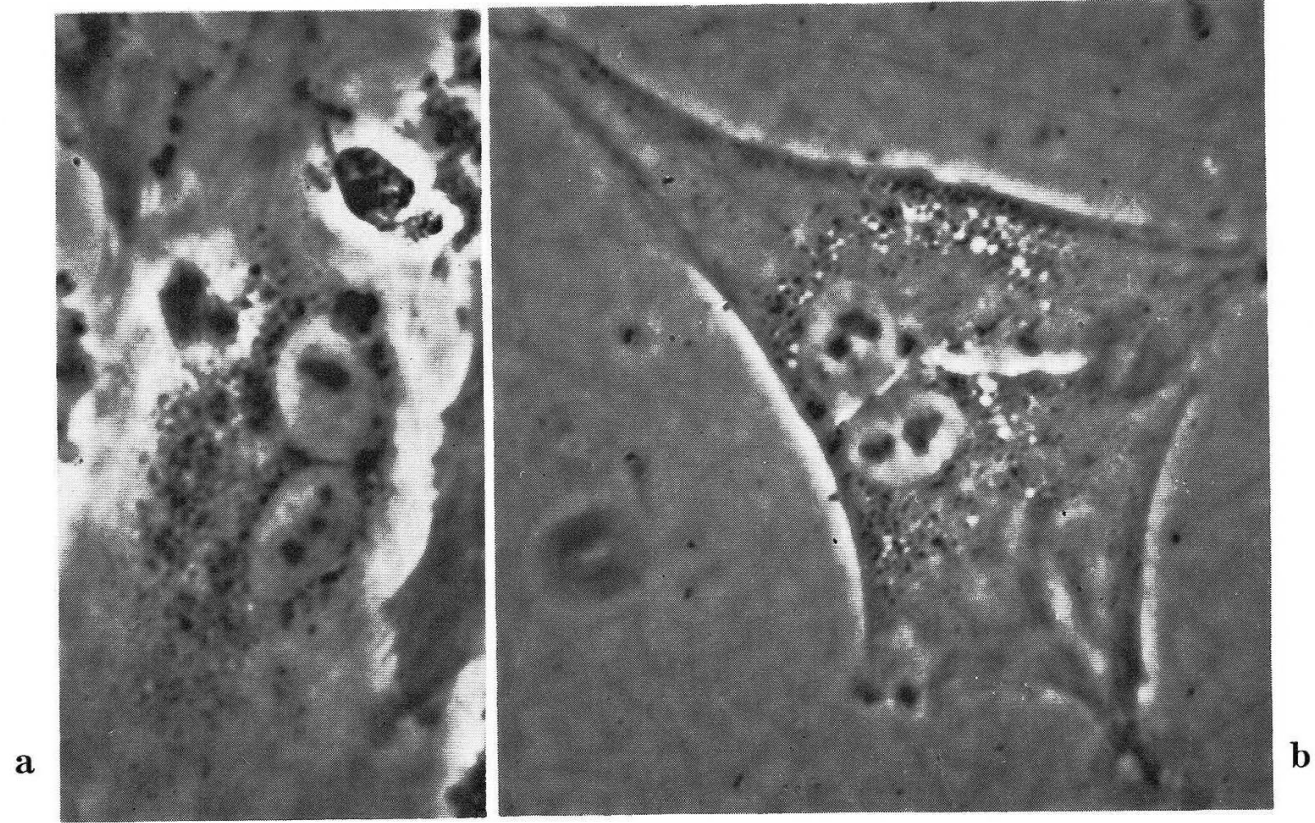

Fig. $2 \mathbf{a}$ and $\mathbf{b}$. Two binucleate endothelial cells are shown. Nuclei of almost same size and shape are in close apposition. 3 day culture. a : $\times 920, \mathbf{b}: \times 800$ 


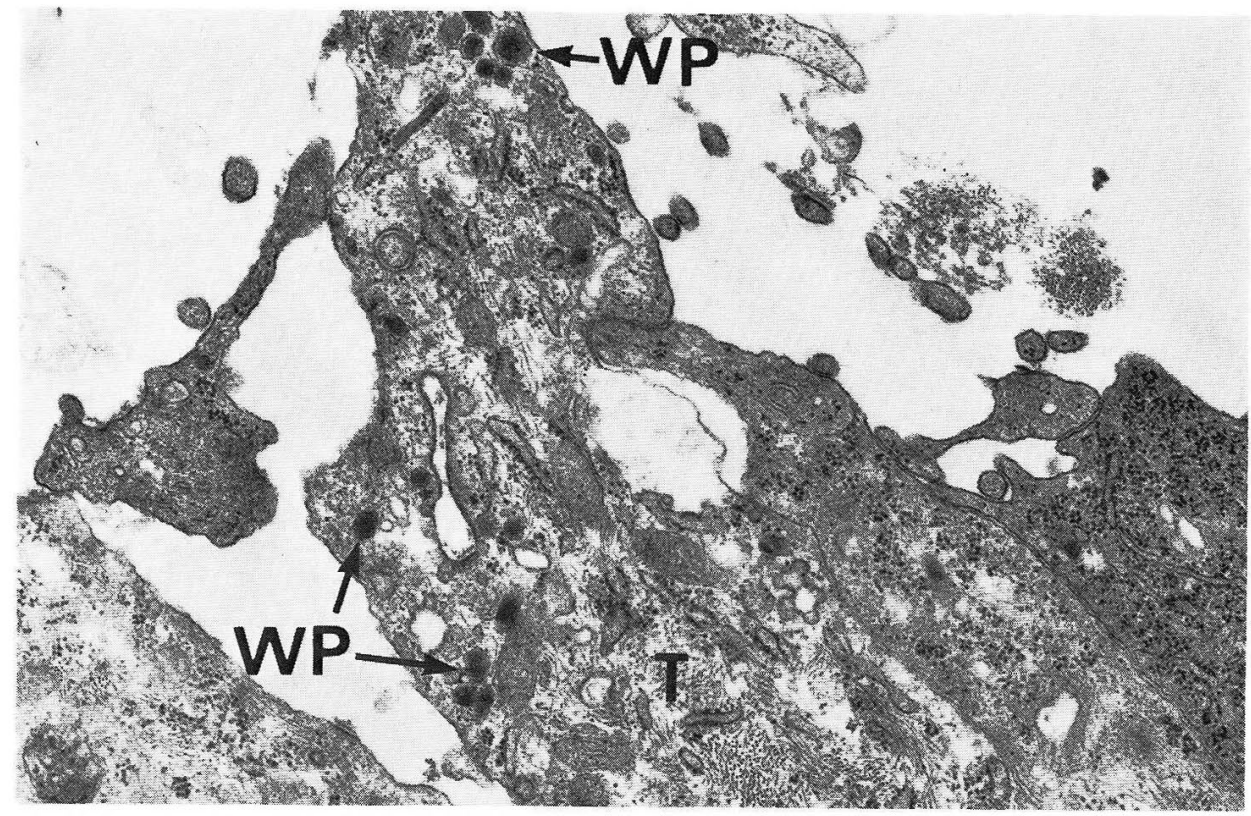

Fig. 3. TEM picture of the cultured cells after 3 days. The cytoplasm contains abundant WeibelPalade granules $(W P)$ and bundles of $120 \AA$ thick filaments $(T) . \quad \times 17,000$

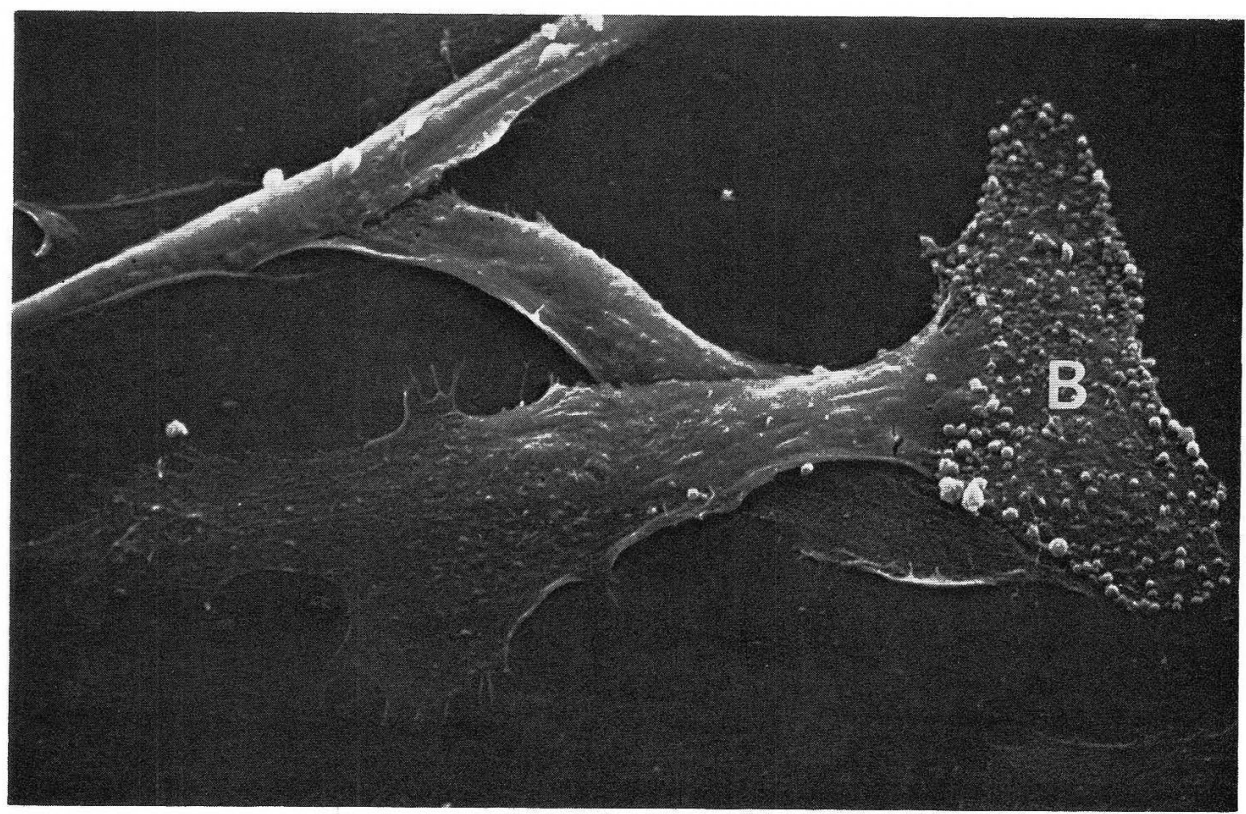

Fig. 4. SEM picture showing the cultured cell surface. Many blebs $(B)$ are seen on the cell surface. 3 day culture. $\times 1,400$ 


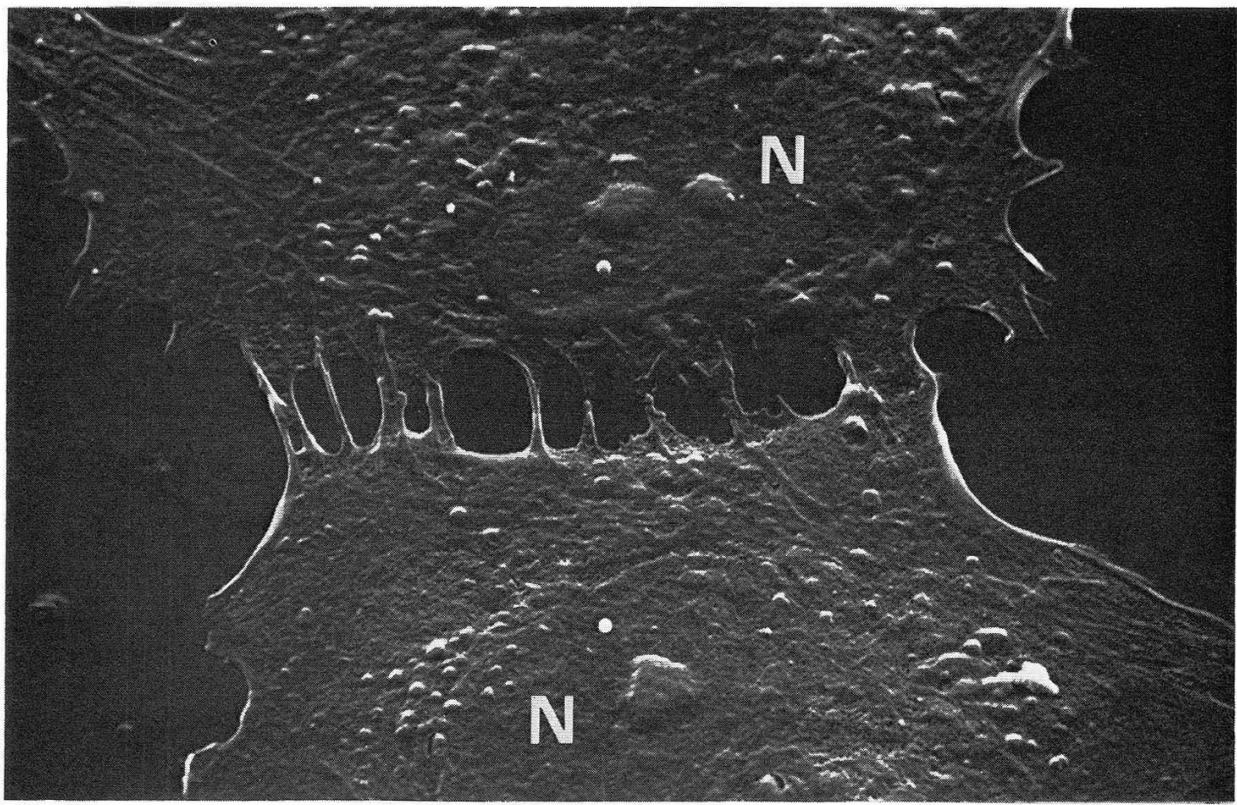

Fig. 5. Two adjacent endothelial cells are in contact with their thin processes. 3 day culture. $N$ nucleus. $\times 2,800$
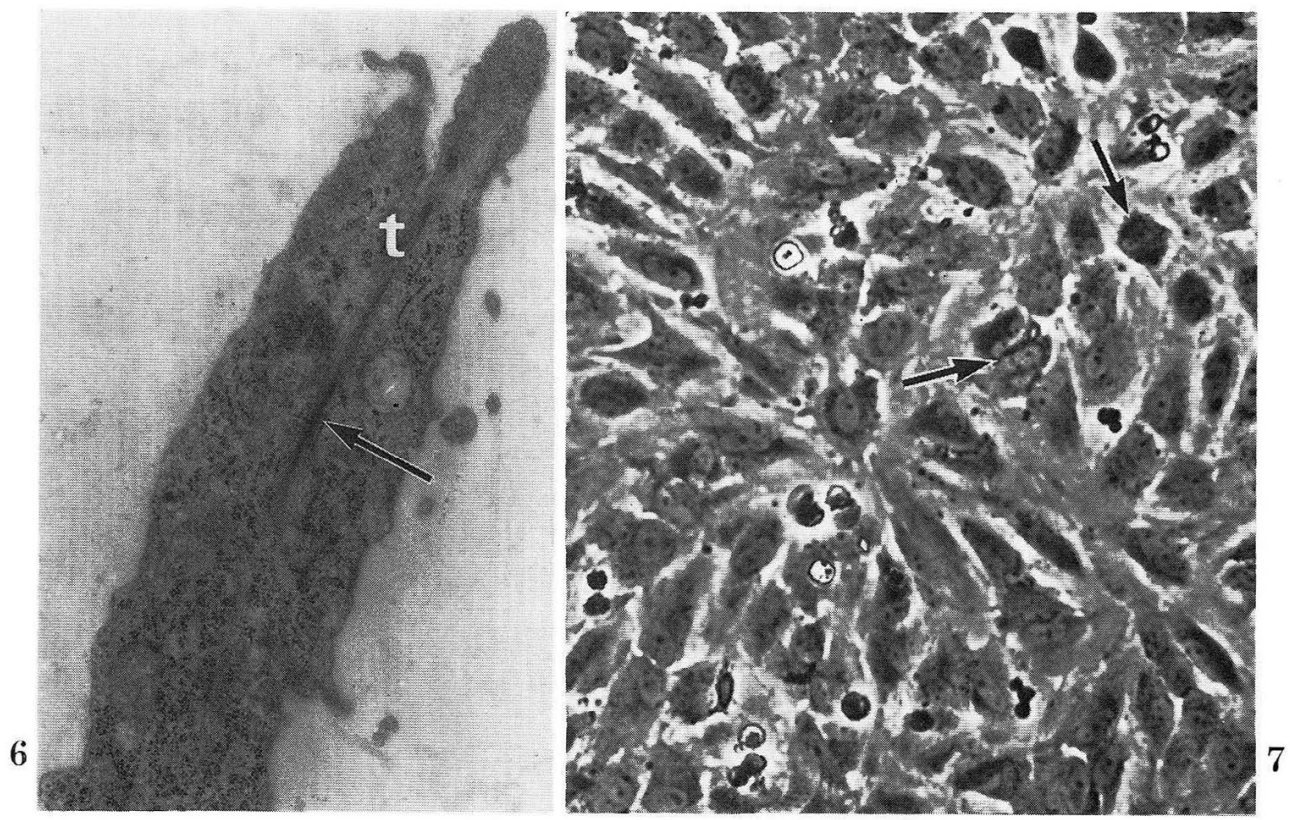

Fig. 6. One end of thinner filaments $(t)$ of $65 \AA$ in diameter is often associated with the cell membrane. The filament bundle has a so-called dense body (arrow). $\times 12,200$

Fig. 7. Phase contrast micrograph of a confluent monolayer of cultured cells after 5 days. Binucleate cells (arrows) still remain. $\times 250$ 

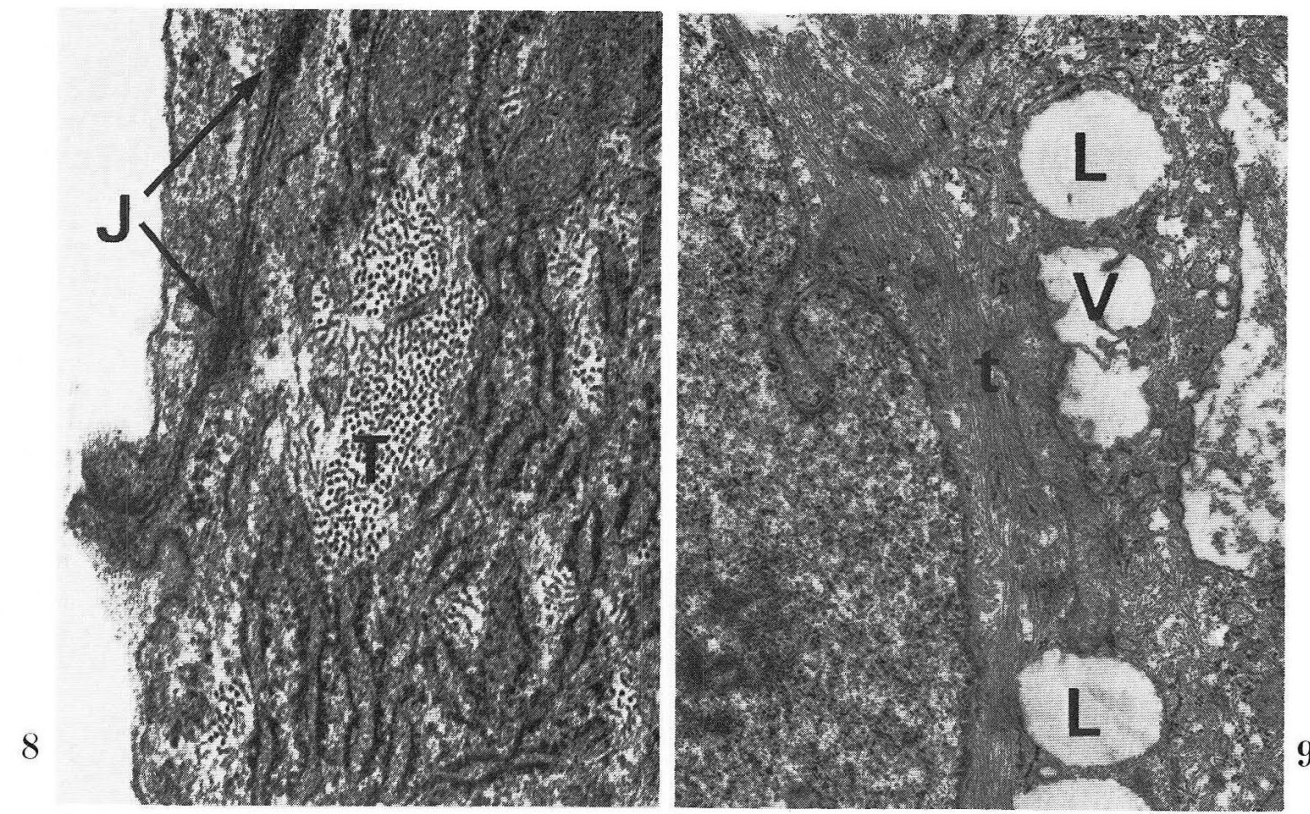

Fig. 8. Two endothelial cells widely contact each other. Note cell junctions $(J)$ with increased density of the adjacent cell membrane. Abundant thicker filaments $(T)$ of $120 \AA$ in diameter are seen. 7 day culture. $\times 34,000$

Fig. 9. Bundle of thinner filaments $(t)$ in the cultured cell after 7 days. $V$ vacuole, $L$ lipid droplet. $\times 14,300$
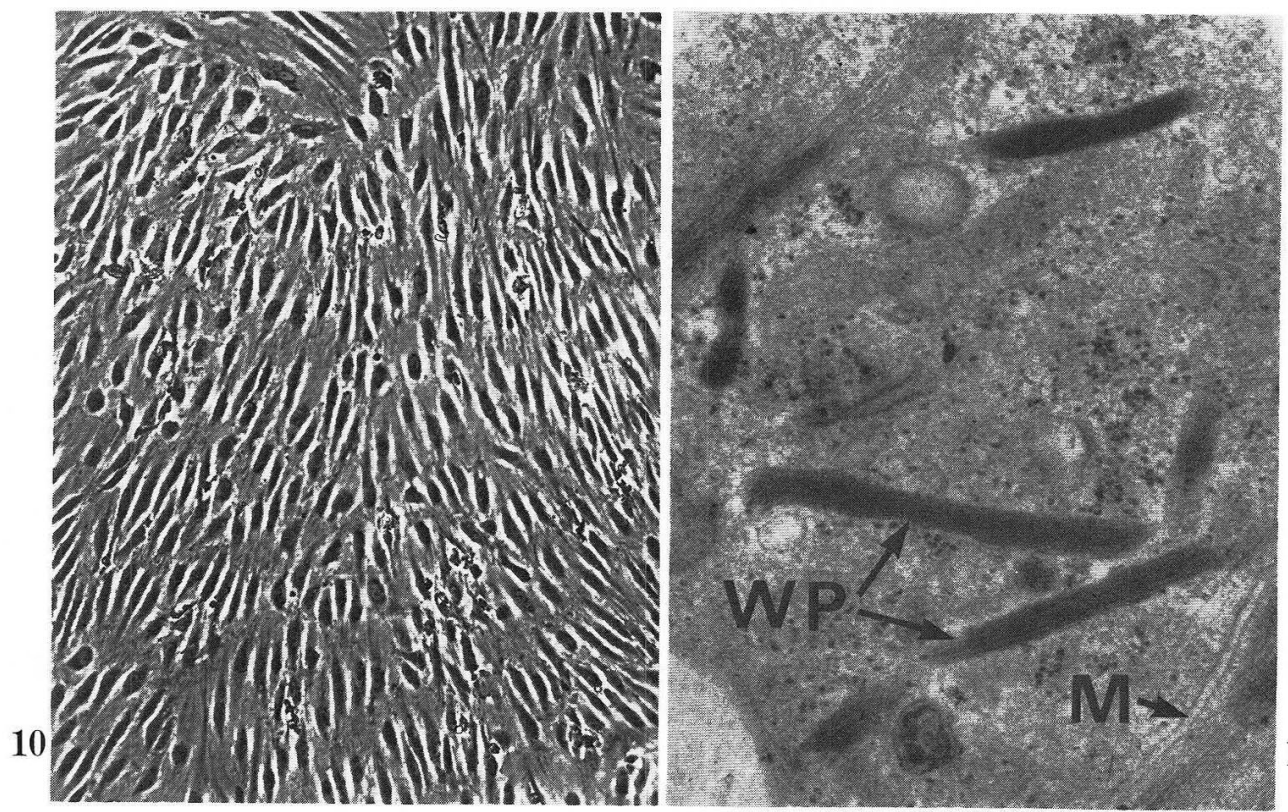

Fig. 10. Low power phase contrast micrograph of a confluent monolayer of the cultured cells. Endothelial cells become spindle forming in shape like fibroblasts. 14 day culture. $\times 100$

Fig. 11. Weibel-Palade granules $(W P)$ in a cultured cell become elongated after 12 days. $M$ microtuble. $\times 33,200$ 
Gimbrone et al., 1974; HAudenschild et al., 1975). The granules increase in number after 3 days (Fig. 3 ) and are the most abundant between 5 and 7 days. During this period, cultured cells also develop two kinds of filaments (about $120 \AA$ and $65 \AA$ in diameters) in their cytoplasm (Fig. 3,6). The thinner filaments always make bundles and run in the peripheral regions of the cytoplasm. They are connected to the cell membrane at one end and are associated with so-called dense bodies similar to those in smooth muscle cells (Fig. 6). The junctions between adjacent cultured cells are not yet developed within 3 days.

Figures 4 and 5 show SEM images of cultured endothelial cells in a 3 day culture. Although most of the cell surface is relatively smooth, many blebs are often seen on the periphery (Fig. 4). They are very flat and irregular in outline with many cytoplasmic extensions by which the adjacent cells are connected to each other (Fig. 5).

Between 5 and 7 days in culture, most cells become polygonal in shape and grow as a confluent monolayer on the whole substratum (Fig. 7). In this stage, the movement of cultured cells was not observed. This may be caused by a contact inhibition as suggested by ABERCRombie (1967). The binucleate cells were still often seen in this stage. TEM observation revealed, well-developed rough endoplasmic reticulum, free ribosomes, abundant filaments of two, vacuoles types and lipid droplets; Weibel-Palade granules were increased in number as compared with the cells in earlier stages (Fig. 8, 9). Attachments between adjacent endothelial cells have been developed and increased their density, and the thicker filaments running parallel along the long axis of endothelial cells are increased in number (Fig. 8).

Between 10 and 14 days in culture, the majority of endothelial cells are elongated into a spindle form like fibroblasts (Fig. 10). The Weibel-Palade granules have decreased in number and remarkably elongated (Fig. 11).

\section{DISCUSSION}

Mitotic figures of endothelial cells are rarely encountered in normal blood vessels except for growing vessels in granulation tissues. On the other hand, the mitotic divisions have been reported in cultured endothelial cells from adult guinea pig arteries and veins (Blose and Chacko, 1975, 1976; Slater and Sloan, 1975). In the present observations, however, the mitotic figures of cultured endothelial cells could not be found in such a rapid proliferation stage as JAFFE and co-workers (1973) characterized as a logarithmic phase of cutured cell growth. On the contrary, binucleate cells were frequently observed in the peripheral regions of each cell cluster where the cultured cells were actively increasing their number. CотTоN and WARTMAN (1961) found occasional binucleate cells in normal human endothelium by the Häutchen technique. In human cultured endothelial cells, Gimbrone and coworkers (1974) showed that labeling indices of ${ }^{3} \mathrm{H}$-thymidine were $2.4 \%$ in closely packed central regions of each cluster and $53.2 \%$ in the peripheral growing regions. This result is compatible with the idea that a rapid DNA synthesis occurs in the binucleate cells. Although mitotic divisions in bi- and trinucleate cells have been demonstrated in mammalian cells of different types (Sisken and KINoshita, 1961; Oftebro and Wolf, 1967), similar events did not seem to occur in the present specimens. 
It is thus concluded that cell proliferation in our human cultured endothelial cells occurs by amitotic division, although possible mitotic division in a few cells can not completely be ruled out.

Recently, it has been reported that tumor cells and their extracts have a capacity to induce the formation of new blood vessels. Thus, production by tumor cells of a tumor angiogenesis factor or an endothelial proliferation factor and their effects causing endothelial proliferation by mitosis in vivo and in vitro have been proposed (Folkman et al., 1971; Cavallo et al., 1972; Suddith et al., 1975). Without administration of such factors, mitotic figures of cultured human endothelial cells have not been demonstrated in any previous experiments (Folkman et al., 1971; Cavallo et al., 1972; Suddith et al., 1975), but in the case of cultures, it may be possible that amitotic divisions are changed into mitotic divisions by the effect of these factors. More detailed observations on cell divisions of cultured human endothelial cells are now in progress with the time-lapse microcinematoscope in our laboratory.

The continual changes of surface structure of the moving cells were observed by microcinematography. In these observations, contraction of such cells induces abundant blebs as also revealed in SEM images (Fig. 4). These blebs can only be seen in actively moving cells through the cell cycle Within the cytoplasm of such cells, dense bodies similar to those found by DEBRUyn and CHo (1974) in endothelial cells of the splenic sinusoids, are associated with thinner filament bundles. Previous investigators demonstrated two types of filaments in the endothelial cells (PHeLPS and Luft, 1969; Yohro and Burnstock, 1973; Becker and Nachman, 1973; Haudenschild et al., 1975) and considered the thinner ones to be contractile elements while the thicker ones, supporting elements. BECKER and Murphy (1969) demonstrated the presence of actomyosin in the endothelial cell of the liver by means of immunofluorescence procedures. The present electron micrographs revealed that actively moving cells constantly develop bundles of thinner filaments in their cytoplasm. The connection between the one end of the filaments and the plasma membrane is apparent. It seems likely that the thinner filaments in the cultured cells are responsible for cell locomotion.

Acknowledgment. The author wishes to express thanks to Prof. Sunao Fujimoto, Department of Anatomy, University of Occupational and Environmental Health, School of Medicine, Kitakyushu, for correcting the manuscript.

\section{培養によるヒト内皮細胞の観察}

\section{山本 硬 治}

培養内皮細胞の日令变化を 位相差顕微鏡，位相差顕微鏡映画 および電子顕微鏡で観察し た.

光学顕微鏡によると，培養細胞は多角形を示し，単層のコロニーを形成するが，10日か ら14日目になると細胞は線維芽細胞様の細長い形をとる．有糸分裂による細胞増殖は位相 差顕微鏡映画で観察できず，むしろ 細胞増殖時期に 多数の二核細胞がコロニー周辺に存 在し，二核細胞の無糸分裂による細胞増殖を強く示唆している. 


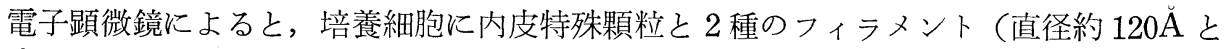
$65 \AA$ ）が認められた，細いフィラメントは 培養細胞の運動に関与する収縮要素であろう と考えられる.

\section{REFERENCES}

Abercrombie, M.: Contact inhibition: the phenomenon and its biological implications. Nat. Cancer Inst. Monogr. 26: 249-277 (1967).

Becker, C. G. and G. E. Murphy : Demonstration of contractile protein in endothelium and cells of the heart valves, endocardium, intima arteriosclerotic plaques, and Aschoff bodies of rheumatic heart disease. Amer. J. Pathol. 55: 1-37 (1969).

Becker, C. G. and R. L. Nachman : Contractile protains of endothelial cells, platelets and smooth muscle. Amer. J. Pathol. 71: 1-20 (1973).

Blose, S. H. and S. Chacko: In vitro behavior of guinea pig arterial and venous endothelial cells. Dev. Growth Differ. 17: 153-165 (1975).

: Rings of intermediate $(100 \AA)$ filament bundles in the perinuclear region of vascular endothelial cells. Their mobilization by Colcemid and mitosis. J. Cell Biol. 70: 459-466 (1976).

Cavallo, T., R. Sade, J. Folkman and R. S. Cotran: Tumor angiogenesis. Rapid induction of endothelial mitoses demonstrated by autoradiography. J. Cell Biol. 54: 408-420 (1972).

Cotton, R. and W. B. Wartman : Endothelial patterns in human arteries. Their relationship to age, vessel site and atherosclerosis. Arch. Pathol. 71: 3-12 (1961).

DeBruyn, P. P. H. and Y. Cho: Contractile structures in endothelial cells of splenic sinusoids. J. Ultrastr. Res. 49: 24-33 (1974).

Folkman, J., E. Merler, C. Abernathy and G. Williams : Isolation of a tumor factor responsible for angiogenesis. J. exp. Med. 133: 275-288 (1971).

Gimbrone, M. A., R. S. Cotran and J. Folkman : Human vascular endothelial cells in culture. Growth and DNA synthesis. J. Cell Biol. 60: 673-684 (1974).

Haudenschild, C. C., R. S. Cotran, M. A. Gimbrone and J. Folkman: Fine structure of vascular endothelium in culture. J. Ultrastr. Res. 50: 22-32 (1975).

Haudenschild, C. C., D. Zahniser, J. Folkman and M. Klagsbrun: Human vascular endothelial cells in culture. Lack of response to serum growth factors. Exp. Cell Res. 98: 175183 (1976).

Jaffe, E. A., R. L. Nachman, C. G. Becker and C. R. Minick: Culture of human endothelial cells derived from umbilical veins. Identification by morphologic and immunologic criteria. J. clin. Invest. 52: 2745-2756 (1973).

Lewis, L. J., J. C. Hoak, R. D. Maca and G. L. Fry : Replication of human endothelial cells in culture. Science 181: 453-454 (1973).

Maruyama, Y.: The human endothelial cell in tissue culture. Z. Zellforsch. 60: 69-79 (1963).

Oftebro, R. and I. Wolf : Mitosis of bi- and multinucleate HeLa cells. Exp. Cell Res. 48: 39-52 (1967).

Phelps, P. C. and J. H. Luft : Electron microscopical study of relaxation and constriction in frog arterioles. Amer. J. Anat. 125: 399-428 (1969).

Sisken, J. E. and R. Kinosita : Variations in the mitotic cycle in vitro. Exp. Cell Res. 22: 521525 (1961).

Slater, D. N. and J. M. Sloan: The porcine endothelial cell in tissue culture. Atherosclerosis 21: 259-272 (1975).

Suddith, R. L., P. J. Kelly, H. T. Hutchison, E. A. Murray and B. Haber : In vitro demon- 
stration of an endothelial proliferative factor produced by neural cell lines. Science 190: 682-684 (1975).

Yohro, T. and G. Burnstock : Filament bundles and contractility of endothelial cells in coronary arteries. Z. Zellforsch. 138: 85-95 (1973).

山本硬治

干 830 久留米市旭町 67

久留米大学医学部

第一解剖学教室
Koji Yамамото

Department of Anatomy

Kurume University School of Medicine

Kurume, 830 Japan 